\title{
ICT Education of future public administration staff oriented to the needs of knowledge society
}

\section{DANA PAĽOVÁ}

\section{ABSTRACT.}

European Union (EU) gets across ambitious transformation from industrial society over information society to declared competitive knowledge society. Governments of EU members' states are investing huge amount of money in the knowledge society to achieve economic growth and international competitiveness. Information and communication technologies (ICT) provide an efficient platform for national knowledge management. Thanks to accessible technology, citizens can actively participate in managing their government and country. Continuous development of ICT not only allows passive dissemination of information but also actively helps in knowledge creation.

Main prerequisites for the successful use of ICT tools for eGovernment purposes are to have developed sufficient infrastructure providing Internet access, well designed and available eGovernment services and digitally literate users on both sides, i.e. as the public officials and citizens themselves.

The paper presents how we are continuously innovating provided education in the field of ICT of specific target group, which will take a part in eGovernment in the future.

\section{REFERENCES}

[1] Council and the European Commission: eEuropa 2002 Action Plan. [online] Available at: http://ec.europa.eu/information_society/eeurope/2002/action_plan/ [Accessed 12 October 2010]

[2] European Commission, 2010: Education and Training Strategic framework for education and training. [online] (Updated 11 June 2010) Available at: http:/ /ec.europa.eu/education/lifelong-learning-policy/doc28_en.htm [Accessed 7 January 2011]

[3] Mihalikov E. and Čisrik P.: Information Management in public administration, 1st ed., Košice: UPJŠ Košice, 2007, pp. 122, ISBN 978-80-7097-691-3 (in Slovak)

[4] Ministry of Education, Science, Research and Sport of Slovak Republic: Reform at a glance. [online] Available at: http://www.minedu.sk/index.php?lang=sk\&rootId=2838 [Accessed 28 January 2011] (in Slovak)

[5] SIBIS Slovakia: Country Report No. 9. [online] Available at: http://www.sibis-eu.org/files/WP5.3_CountryReport_SK.pdf [Accessed 10 January 2011]

[6] Velšic M.: Digital Literacy and Labour Market. [online] Bratislava: The Institute for Public Affairs. Available at: http://www.ivo.sk/6191/sk/studie/-digitalna-gramotnost-a-trh-prace [Accessed 10 December 2010] (in Slovak)

DEPARTMENT OF APPLIED MATHEMATICS AND BuSINESS INFORMATICS

TECHNICAL UNIVERSITY OF KoŠICE, SLOVAKIA

Nemcovej 32, 04001 KoŠıce, SlovaKia

E-mail address: dana.palova@tuke.sk

Received: 30.10.2011; In revised form: 14.11.2012; Accepted: 30.01.2013

2010 Mathematics Subject Classification. 97C30, 97B40, 97U70, 97C80.

Key words and phrases. Higher education, knowledge society, eGovernment, digital literacy, education of public administration staff. 